\title{
Optimization of lactic acid bacteria viability using fuzzy soft set modelling
}

\author{
Reyhan Irkin ${ }^{a}$, Nihal Yılmaz Özgür ${ }^{b^{*}}$ and Nihal Taşs \\ ${ }^{a}$ Department of Nutrition and Dietetics, Izmir Democracy University, Turkey \\ ${ }^{b}$ Department of Mathematics Ballkesir University, Turkey \\ reyhan.irkin@idu.edu.tr,nihal@balikesir.edu.tr,nihaltas@balikesir.edu.tr
}

\section{ARTICLE INFO}

\section{Article History:}

Received 15 February 2017

Accepted 14 June 2018

Available 31 July 2018

\section{Keywords:}

Pickle

Salt concentration

Lactic acid bacteria

Optimization

Fuzzy soft set

AMS Classification 2010:

03E72, 06D72, 54A40, 97E60

\section{ABSTRACT}

Lactic acid fermented vegetables are important sources of vitamins and minerals. In recent years consumers demand for non-dairy based functional products has increased. Cabbage pickle has high enough concentrations of fiber and also it may show health effect with the containing high numbers of lactic acid bacteria. The aim of this study is to optimize mathematically cabbage-carrot pickle fermentation for the viability of Lactobacillus acidophilus, Lactobacillus casei cultures and the sensory scores in brine with $5 \%$ and $7 \%(\mathrm{w} / \mathrm{v})$ salt concentrations. Viability optimization of lactic acid bacteria is done via the notion of "fuzzy soft set" method. Lb. casei, Lb. acidophilus, total lactic acid bacteria, Enterobacteriaceae sp., yeast-mould counts and $\mathrm{pH}$ values have been reported during the 30 days of storage. The results are compared with the control traditional fermented cabbage-carrot pickle. Organoleptic properties are evaluated. We conclude that the fermented pickle samples contain a significant number of beneficial lactic acid bacteria and high sensory marks at the end of the storage.

(cc) $\mathrm{BY}$

\section{Introduction}

Nowadays consumers pay a lot of attention to the relation between food and health. The market for foods with health promoting properties called functional foods has shown remarkable growth over the last years. In this context, functional foods have received considerable attention in recent years [1.

Functional lactic acid bacteria can reduce the number of undesired microorganisms in vegetable products [2. It has some functions on antibioticassociated diarrhea and immune system functions 3]. Lb. acidophilus and $L b$. casei produce lactic acid as the main end product of fermentation. In addition, lactic acid bacteria produce hydrogen peroxide, diacetyl and bacteriocin as antimicrobial substances. $L b$. acidophilus strains can exert anti-listerial bactericidal activity which could be of great technological importance (see [3] and [4] for more details). Also, Lb. casei decreased the severity of infection with Salmonella enterica serovar Typhimurium, a daily supplementation of $L b$. acidophilus during post antibiotic therapy reduced the extent of disruption to the intestinal microbiota (see [3] and [5] for more details). These strains can prevent allergic disease, reducing lactose intolerance, enhancing bioavailability of nutrients. Researchers reported that $L b$. acidophilus (acidolin, acidophilin producer) into the diet lowers the incidence of chemically induces colon tumors in rats (see [3] and [6] for more details).

Vegetables are good sources of natural antioxidants such as carotenoids, vitamins, minerals and dietary fibers. Vegetables may be preserved by fermentation, direct acidification, or a combination of other processing conditions and additives

*Corresponding Author 
to yield products that are referred to as pickles. Cucumbers, cabbages, olives, peppers account for the largest volume and lesser quantities of onions, tomatoes, cauliflowers, carrots, melon rinds, okra, artichokes, beans etc. are also pickled. This method of food preservation has been used for many centuries [7]. Fermented vegetables are good sources of lactic acid bacteria (LAB). Representatives of some important genera such as Leuconostoc, Lactobacillus, Lactococcus and Pediococcus are found in fermented vegetables. It was reported that Leuconostoc sp. was the main species in the early stages of fermentation, while Lactobacillus sp. became predominant with the $\mathrm{pH}$ value gradually falling to 4.0 [8]. Plant fibers provide a promising alternative to suppress systemic inflammation, to reduce the risk of developing other chronic diseases and to considerably improve quality of life. Treatment with specific lactic acid bacteria and plant fibers has shown a unique ability to suppress inflammation in animal models and to prevent destruction of tissues [9].

The usage of starter culture (Lactic acid bacteria - LAB) performs food safety and causes rapid decrease of the $\mathrm{pH}$. The controlled fermentation of pickles reduces economic losses and leads to get uniform quality product over a short period time. In the last years, $L b$. casei and $L b$. acidophilus were began to use in vegetable and fruit juice based products such as tomato, cabbage, beet, orange, pineapple, carrot, grape juices (see [10], [11] and [12] for more details). The high salt levels are used to select for naturally occurring, heterofermentative and homofermentative lactic acid bacteria (LAB) to carry out the fermentation and then to protect against spoilage after the active fermentation period. However, health authorities recommend a reduction of the salt content in food and nowadays consumers of industrialised countries demand low-salt foods for health reasons (see [6], [13], 14] and [15] for more details).

In this study our aim is to establish the growth prediction models under two different salinity conditions $(5 \%$ and $7 \% \mathrm{w} / \mathrm{v})$ for two critical microorganisms of $L b$. casei and $L b$. acidophilus in functional pickled cabbage-carrot processing involved. We analyze the obtained results using the notion of a fuzzy soft set. There exist some applications of the notions of "soft set" and "fuzzy soft set" in many areas of science (see [16], [17, [18, [19] and [20] for more details). This study is the first application of the fuzzy soft set theory in food engineering. By this approach, it can be easily optimize the results by using appropriate parameters and degree of membership functions. We see that this decision making method gives accurate and adequate predicts.

\section{Materials and methods}

In this section we explain our approach and methods.

\subsection{Pickle production}

Cabbage and carrots were bought from a local market in Balıkesir, Turkey. Cabbage outer leaves were separated and after cut the halves, all pieces shredded small pieces (about $2 \times 2 \times 0.02 \mathrm{~cm}^{3}$ dimensions), they washed with tap water before treatment rinsed with a disinfectant (SurfceraVegisafe, Japan) solution. Carrots were trimmed, washed and cut into slices. After that cabbage and carrot pieces were mixed and divided into the groups and filled into the glass-jars.

$5 \%$ and $7 \%$ of $(\mathrm{w} / \mathrm{v}) \mathrm{NaCl}$ were added in to the tap water. Brine solutions were sterilized at $100^{\circ} \mathrm{C} / 20 \mathrm{~min}$ and cooled to $20^{\circ} \mathrm{C}$. Garlic $10 \mathrm{~g} / \mathrm{lt}$, Saccharose $5 \mathrm{~g} / \mathrm{lt}$, Grape vinegar $10 \mathrm{ml} / \mathrm{lt}$ were added into the per jar and brine solution were filled completely in pickle jars.

\subsection{Bacterial cultures}

Lactobacillus casei (NRRL B-1922) and Lactobacillus acidophilus (NRRL B-4495) freeze-dried strains were obtained from United States Department of Agriculture, Illinois, US. They activated in sterilized Liver Infusion Broth (Difco, US) and then activated young culture $\left(10^{10} \mathrm{cfu} / \mathrm{ml}\right)$ of them added $(5 \mathrm{ml} / \mathrm{lt})$ into the pickle jars and mixed homogeneously. Lactic acid bacteria were not added into the control groups. $L b$. casei and Lb. acidophilus as starter cultures were inoculated about $10^{8} / \mathrm{ml}$ into the samples and the number of total lactic acid bacteria was $10^{6} / \mathrm{ml}$ on raw vegetables before the fermentation process. $L b$. casei is one of the normal microflora bacterium in pickles and it was determined as $<2 \log \mathrm{cfu} / \mathrm{g}$ in control pickle groups. Lb. acidophilus was not found in control pickles.

At first, pickles were incubated in $35^{\circ} \mathrm{C} / 8 \mathrm{~h}$ growing conditions for $L b$. acidophilus and Lb.casei (see [21] and [22] for more details) for developing acidity. Then they were incubated at $20{ }^{\circ} \mathrm{C} / 15$ $\mathrm{d}\left[23\right.$ after that they stored in refrigerator at $4^{\circ} \mathrm{C}$. Acidity, viable numbers of $L b$. casei, $L b$. acidophilus, total lactic acid bacteria and yeast and mould counts were determined in 1., 4., 10., 17. and 30 . days. 


\subsection{Microbiological analysis}

Samples were diluted in (1:10) in Buffered Peptone Water $(\mathrm{BPW})$ and homogenized for $20 \mathrm{~s}$ in a stomacher (Bag mixer, Interscience, FR). Subsequently, a decimal dilution series made in BPW and enumeration was performed by pour plate or spread plating techniques (see Table 1).

Table 1. Media and incubation conditions used for determining microorganism numbers.

\begin{tabular}{|l|l|l|}
\hline Microorganism & Media & Incubation conditions \\
\hline Total lactic acid bacteria numbers & Man Rogosa Sharpe agar & $30^{\circ} \mathrm{C} / 2-3 \mathrm{~d}$ \\
\hline Lb. casei number & MRS-Vancomycine agar 2 & $30^{\circ} \mathrm{C} / 2-3 \mathrm{~d}$ \\
& ml/l vancomycine $(0.05 \mathrm{~g}$ & \\
& vancomycine/100 ml in & \\
& MRS. & \\
\hline Lb. acidophilus number & MRS-Sorbitol agar $(10 \mathrm{ml}$, & $35^{\circ} \mathrm{C} / 2-3 \mathrm{~d}$ \\
& $10 \% \quad(\mathrm{w} / \mathrm{v})$, D-Sorbitol $/ 90$ & \\
\hline Enterobacteriaceae sp. & ml agar) & \\
\hline Yeast-Mold numbers & Violet Red Bile Dextrose & $37^{\circ} \mathrm{C} / 24 \mathrm{~h}$ \\
\hline
\end{tabular}

\subsection{Sensory analysis}

After the 30 days of storage, the products were sensorially evaluated for taste, odor, color, texture, and overall acceptability by a panel consisting of 7 sensory experts. The panelists, who have considerable background knowledge in sensory evaluation, were selected from the staff, researchers. The score given by the panel varied from 1 (dislike extremely) to 5 (like extremely). The sensory characteristics of odor, texture, and taste were assessed on each test sample. Sensory analysis of the pickle sample was evaluated explaining the following descriptors - salty, acidic sourness, sweet acidic, smelly, bitter, kraut sulfur flavor, raw cabbage flavor, discoloration, pleasant aroma and overall acceptability. A sample was considered as unacceptable for a sensory characteristic if the score was less than 2.5 (see [24] and [25] for more details).

\subsection{Decision making via "Fuzzy Soft Sets"}

We optimize the lactic acid bacteria viability and sensory acceptability in the production of white cabbage-carrot pickle fermentation in different salinity conditions by means of "fuzzy soft sets " 26] modelling. At first, the membership functions which through all of the results using MATLAB (Matlab R 2015 a and Curve Fitting Toolbox -Version 8.5, The Mathworks, Inc., Natick, Massachusetts, United States) for $\mathrm{pH}, L b$. casei, $L b$. acidophilus, lactic acid bacteria and yeastmold numbers were constructed. It was used the notion of "fuzzy soft set" to optimize the results. To do this it was defined a universal set and a parameter set. Fuzzy soft sets were obtained by use of the membership functions, the universal set and the parameter set. Finally, Table 3 was constructed using the values of membership functions and matrix theory [18]. Using this table it can be decided the most appropriate salt concentration in pickles and compared with the sensory scores.

\section{Results}

In this section we present the obtained results.

\subsection{Acidity results}

The usage of the starter culture performs food safety and causes rapid decrease of the $\mathrm{pH}$. Decline of the $\mathrm{pH}$ resulted in all pickle samples with $5 \%$ and $7 \%$ salt (w/v) brine conditions. Rapid increases of active culture in the pickles caused optimum fermentation conditions and decreasing of the $\mathrm{pH}$.

\subsection{Microbiological analysis results}

In our study, $L b$. casei in $7 \%(\mathrm{w} / \mathrm{v})$ salt concentration was affected from low $\mathrm{pH}$ (3.32) and high salt concentration conditions and the numbers were low $(7.85 \log \mathrm{cfu} / \mathrm{gr})$ than the others at the end of the storage (see Figures 114). At the first day of fermentation $L b$. casei numbers were 7.74 and $9.02 \mathrm{log} \mathrm{cfu} / \mathrm{g}$ in pickles with $5 \%(\mathrm{w} / \mathrm{v})$ and $7 \%(\mathrm{w} / \mathrm{v})$ brine solution, respectively. However, at the end of the storage $L b$. casei numbers were reached to $8.7 \mathrm{log} \mathrm{cfu} / \mathrm{g}$ in pickles with $5 \%$ $(\mathrm{w} / \mathrm{v})$ brine solution and $7.85 \mathrm{log} \mathrm{cfu} / \mathrm{g}$ with $7 \%$ $(\mathrm{w} / \mathrm{v})$ brine solution. 


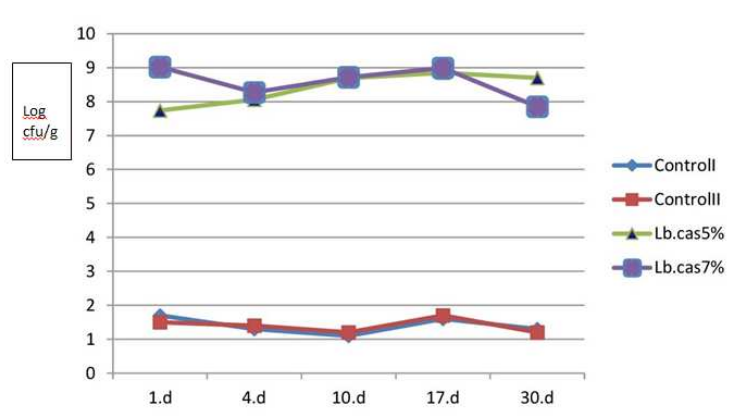

Figure 1. Lb. casei numbers (log CFU/gr).

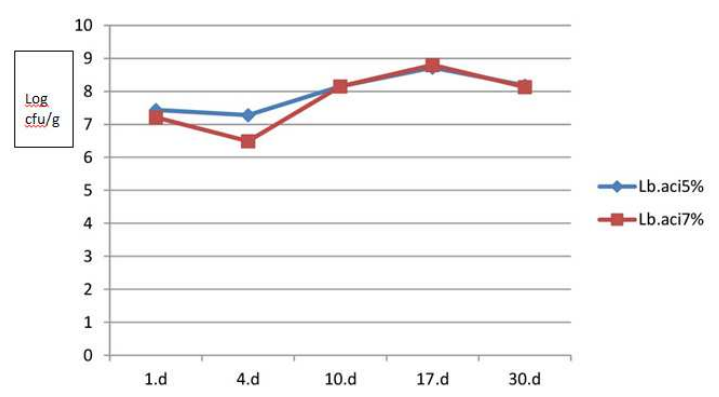

Figure 2. $L b$. acidophilus numbers $(\log \mathrm{CFU} / \mathrm{gr})$.

Total lactic acid bacteria numbers were determined as max. 9.5 and $8.88 \mathrm{log} \mathrm{cfu} / \mathrm{g}$ for $L b$. $c a$ sei and $L b$. acidophilus, respectively on the $17^{\text {th }}$ day of storage of $7 \%(\mathrm{w} / \mathrm{v})$ brine solutions. However, it was found that 8.66 and $8,72 \mathrm{log} \mathrm{cfu} / \mathrm{g}$ for $L b$. casei and Lb. acidophilus numbers in $5 \%$ $(\mathrm{w} / \mathrm{v})$ brine solutions in the same day. After the 30 days of storage $L b$. casei numbers decreased to 7.77 and $7.6 \log \mathrm{cfu} / \mathrm{g}$ in $7 \%$ and $5 \%(\mathrm{w} / \mathrm{v})$ salt concentration brine, respectively (see Figure 3).

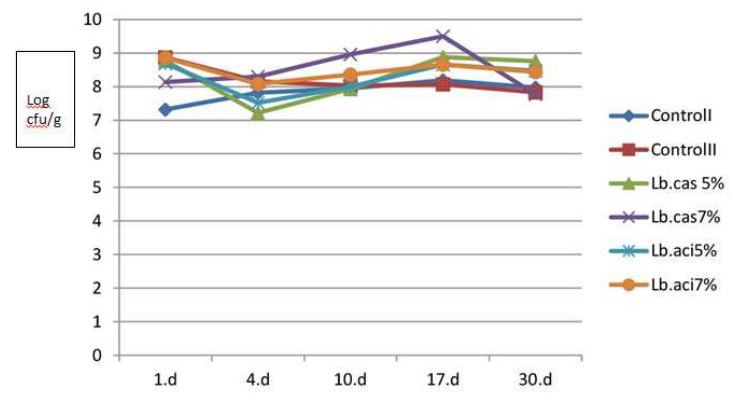

Figure 3. Total lactic acid bacteria (LAB) numbers (log CFU/gr).

Moulds didn't grow in any pickles. Only some yeasts were observed. Yeast numbers showed a sharply decline during the 30 days (see Figure 4). Maximum yeast numbers were $5.16 \mathrm{log} \mathrm{cfu} / \mathrm{g}$ in Lb. casei containing pickles with $5 \%(\mathrm{w} / \mathrm{v})$ salt concentrations brine on the first day. Then, minimum yeast numbers were determined as $0.28 \mathrm{log}$ $\mathrm{cfu} / \mathrm{g}$ in $\mathrm{Lb}$. acidophilus containing pickles with
$7 \%(\mathrm{w} / \mathrm{v})$ salt concentrations brine on the $30^{\text {th }}$ day.

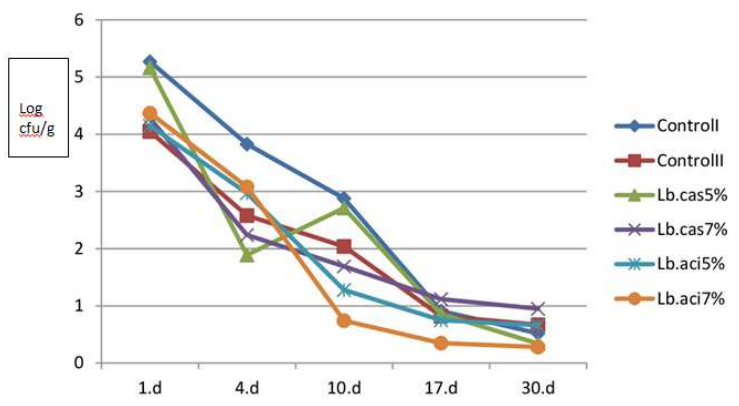

Figure 4. Total yeast numbers (log $\mathrm{CFU} / \mathrm{gr}$ ) during the storage of pickles.

In research, Enterobacteriacea spp. were not determined in pickles and it can be thought that because of washing vegetables with a disinfectant solution before treatments cause inhibition effects on these groups of bacteria.

\subsection{Sensory analysis results}

From the Figure 5, we can see that the sensory analysis results. Using these results we deduce that the pickles with $L b$. casei culture in $5 \%$ salt concentration were preferred according to the overall, colour, taste and odour quality properties. But the texture of the pickles with $7 \%$ salt concentrations have higher scores than the others.

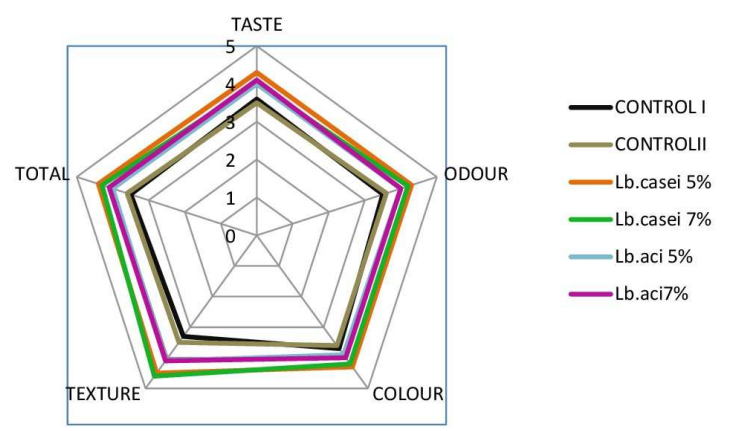

Figure 5. Sensory profile of pickle samples during the storage of 30 days.

\subsection{Microbial analysis via fuzzy soft sets}

Now we analyze the obtained results using the notion of "fuzzy soft set". The notion of a fuzzy soft set was introduced in [26] as follows:

Let $U$ be a universal set, $E$ be a set of parameters and $A \subset E$. Let $P(U)$ denotes the set of all fuzzy subsets of $U$. Then a pair $(F, A)$ is called a fuzzy soft set over $U$, where $F$ is mapping from $A$ to $P(U)$.

Following algorithm can be presented for optimization of the salt concentration : 
Step 1. Defining a universal set $X$ and a parameter set $E$.

Step 2. Using MATLAB (Curve Fitting Toolbox- 2015), choose appropriate functions through all of the results obtained for $p h, l c, l a$, $l a b$ and $y m$, respectively.

Step 3. Using the functions chosen in Step 2, define the membership functions for $p h, l c, l a, l a b$ and $y m$, respectively.

Step 4. Constructing the fuzzy soft sets $\left(F_{x, i}, E_{i}\right), i=1$ to 6 where $x \in\{1,4,10,17,30\}$.

Step 5. Computing the fuzzy soft sets $\left(F_{30, i}, E_{i}\right)$, $i=1$ to 6 .

Step 6. Constructing a table of the fuzzy soft sets $\left(F_{30, i}, E_{i}\right)$ and insert " 0 " or " 1 " for each $E_{i}$, $i=1$ to 6 .

Step 7. Adding sensory scores column obtained by a panel consisting of 7 sensory experts to the above table.

Step 8. Making decision is the $E_{i},(i=1$ to 6$)$ which has the top score " 1 ".

Then, data can be established by fuzzy soft modeling to optimize the results as follows:
It can be defined the following notations:

$p h: p H$ value,

$l c:$ Lb. casei number,

$l a:$ Lb. acidophilus number,

lab : Lactic acid bacteria numbers,

ym : Yeast - mold number,

and

$E_{1}:$ Control $\% 5$,

$E_{2}$ : Control \%7,

$E_{3}: L b$. casei $\% 5$,

$E_{4}: L b$. casei $\% 7$,

$E_{5}: L b$. acido $\% 5$,

$E_{6}: L b$. acido $\% 7$.

A universal set and a parameter set were defined as follows, respectively:

$$
X=\{p h, l c, l a, l a b, y m\},
$$

and

$$
E=\left\{E_{1}, E_{2}, E_{3}, E_{4}, E_{5}, E_{6}\right\}
$$

Table 2. $\mathrm{pH} \pm$ standard deviations (S.D.) of pickles during the storage at (1., 4., 7., 10., 17. and 30. days) $+4{ }^{\circ} \mathrm{C}$.

\begin{tabular}{|l|l|l|l|l|l|}
\hline Products & $\mathbf{1}$ & $\mathbf{4}$ & $\mathbf{1 0}$ & $\mathbf{1 7}$ & $\mathbf{3 0}$ \\
\hline Control I 5\% & $3.44 \pm 0.4$ & $3.47 \pm 0.5$ & $3.40 \pm 0.4$ & $3.35 \pm 0.2$ & $3.34 \pm 0.8$ \\
\hline Control II 7\% & $3.58 \pm 0.6$ & $3.61 \pm 0.9$ & $3.55 \pm 0.5$ & $3.41 \pm 0.5$ & $3.39 \pm 0.4$ \\
\hline Lb.casei 5\% & $3.83 \pm 0.3$ & $3.70 \pm 0.7$ & $3.52 \pm 0.7$ & $3.45 \pm 0.5$ & $3.39 \pm 0.5$ \\
\hline Lb. casei 7\% & $3.73 \pm 0.5$ & $3.59 \pm 0.6$ & $3.44 \pm 0.9$ & $3.33 \pm 0.6$ & $3.32 \pm 0.7$ \\
\hline Lb. acidophilus 5\% & $3.62 \pm 0.7$ & $3.55 \pm 0.3$ & $3.48 \pm 0.6$ & $3.40 \pm 0.4$ & $3.36 \pm 0.2$ \\
\hline Lb. acidophilus 7\% & $3.63 \pm 0.4$ & $3.55 \pm 0.8$ & $3.46 \pm 0.3$ & $3.42 \pm 0.9$ & $3.39 \pm 0.5$ \\
\hline
\end{tabular}

Appropriate functions such as $p h_{i}, l c_{i}, l a_{i}, l a b_{i}$, $y m_{i}$ were chosen using MATLAB (Curve Fitting Toolbox-2015) where $i \in\{1,2,3,4,5,6\}$. Then it was given membership functions for $\mathrm{pH}, L b$. casei numbers, $L b$. acidophilus numbers, lactic acid bacteria numbers and yeast - mold numbers as the following cases:

Case1: Using MATLAB - Curve Fitting Toolbox and the results given in Table 2, following functions for $\mathrm{pH}$ value (see Figure 6) were chosen:

$$
\begin{aligned}
& p h_{1}(x)=0.0004 x^{3}-0.0068 x^{2}+0.0371 x+3.4094 \\
& p h_{2}(x)=0.0001 x^{3}-0.0030 x^{2}+0.0223 x+3.5619 \\
& p h_{3}(x)=0.0026 x^{2}-0.0580 x+3.8882 \\
& p h_{4}(x)=0.0017 x^{2}-0.0491 x+3.7719 \\
& p h_{5}(x)=0.0004 x^{2}-0.0205 x+3.6352, \\
& p h_{6}(x)=0.0015 x^{2}-0.0329 x+3.6606,
\end{aligned}
$$
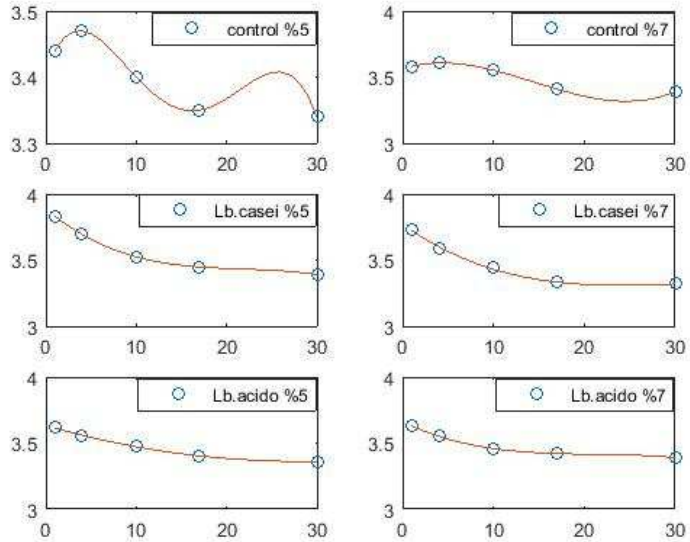

Figure 6. The graphics of the membership functions for $\mathrm{pH}$ value (the $\mathrm{x}$ axis represent the days and the $y$-axis represent the $\mathrm{pH}$ values). 


$$
\mu_{i}^{p h}(x)=\frac{p h_{i}(x)}{10^{n}}
$$

for all $i \in\{1,2,3,4,5,6\}$, where $n$ is the number of digits of the integer part of $p h_{i}(x)$.

Case 2: By a similar way, using the results given in Figure1, following functions for $L b$. casei number (see Figure 7) were chosen:

$$
\begin{aligned}
& l c_{3}(x)=-0.0010 x^{3}+0.0123 x^{2}+0.0656 x \\
& +7.6632 \\
& l c_{4}(x)=0.0001 x^{4}-0.0049 x^{3}+0.0963 x^{2} \\
& -0.6350 x+9.5735
\end{aligned}
$$

where $x \in\{1,4,10,17,30\}$.
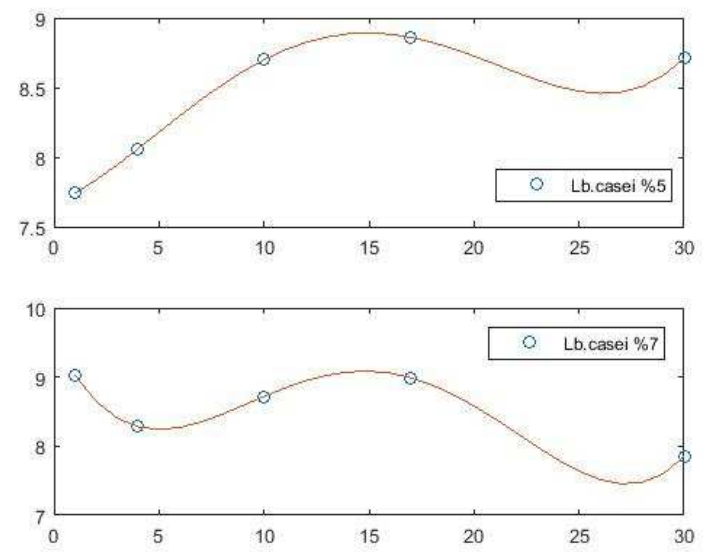

Figure 7. The graphics of the membership functions for $L b$. casei number (the $\mathrm{x}$-axis represent the days and the y-axis represent the $L b$. casei numbers).

The following membership function was defined

$$
\mu_{i}^{l c}(x)=\left\{\begin{array}{c}
\frac{l c_{i}(x)}{10^{n}} \text { if } i \in\{3,4\} \\
0 \text { if otherwise }
\end{array}\right.
$$

for all $i \in\{1,2,3,4,5,6\}$, where $n$ is the number of digits of the integer part of $l c_{i}(x)$.

Case 3: Using the results given in Figure 2, following functions for $L b$. acidophilus number were chosen (see Figure 8):

$$
\begin{aligned}
& l a_{5}(x)=0.0001 x^{4}-0.0035 x^{3}+0.0657 x^{2} \\
& -0.3156 x+7.7034 \\
& l a_{6}(x)=0.0002 x^{4}-0.0098 x^{3}+0.1760 x^{2} \\
& -0.9286 x+7.9723,
\end{aligned}
$$

where $x \in\{1,4,10,17,30\}$.
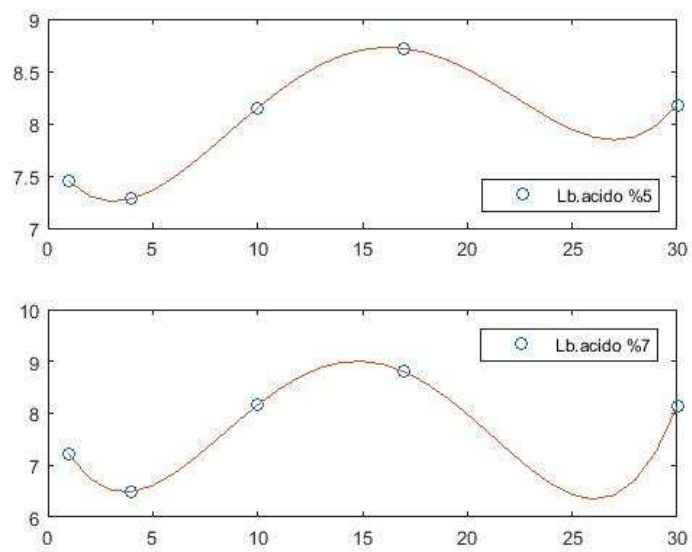

Figure 8. The graphics of the membership functions for $L b$. acidophilus number (the $\mathrm{x}$-axis represent the days and the y-axis represent the $L b$. acidophilus numbers).

The following membership function was defined

$$
\mu_{i}^{l a}(x)=\left\{\begin{array}{c}
\frac{l a_{i}(x)}{10^{n}} \text { if } i \in\{5,6\} \\
0 \text { if otherwise }
\end{array},\right.
$$

for all $i \in\{1,2,3,4,5,6\}$, where $n$ is the number of digits of the integer part of $l a_{i}(x)$.

Case 4: Using the results given in Figure 3, it can be chosen the following functions for lactic acid bacteria numbers (see Figure 9):

$$
\begin{aligned}
& l a b_{1}(x)=0.0023 x^{3}-0.0430 x^{2}+0.3338 x+7.0369, \\
& l a b_{2}(x)=-0.0028 x^{3}+0.0592 x^{2}-0.4768 x+9.2904, \\
& l a b_{3}(x)=0.0001 x^{4}-0.0087 x^{3}+0.1778 x^{2}-1.2342 x \\
& +9.8350, \\
& l a b_{4}(x)=-0.0008 x^{3}+0.0172 x^{2}-0.0160 x+8.1396, \\
& l a b_{5}(x)=0.0001 x^{4}-0.0064 x^{3}+0.1315 x^{2}-0.9209 x \\
& +9.4857, \\
& l a b_{6}(x)=0.0001 x^{4}-0.0045 x^{3}+0.0891 x^{2}-0.6211 x \\
& +9.4065,
\end{aligned}
$$

where $x \in\{1,4,10,17,30\}$. 

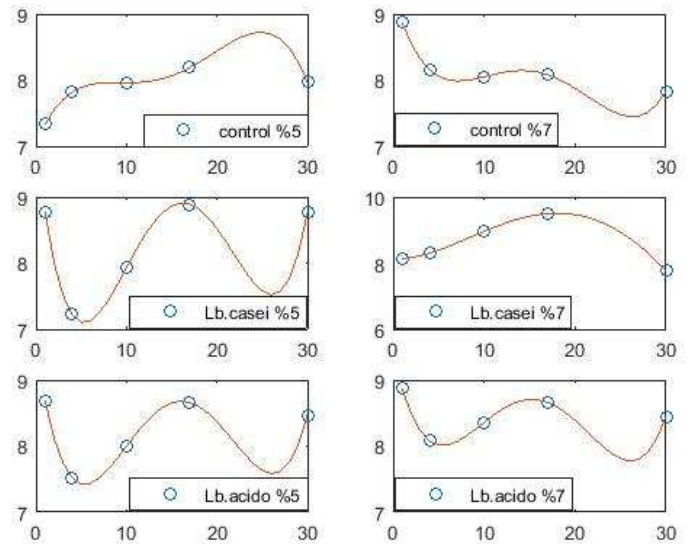

Figure 9. The graphics of the membership functions for lactic acid bacteria numbers (the $\mathrm{x}$-axis represent the days and the y-axis represent the lactic acid bacteria numbers).
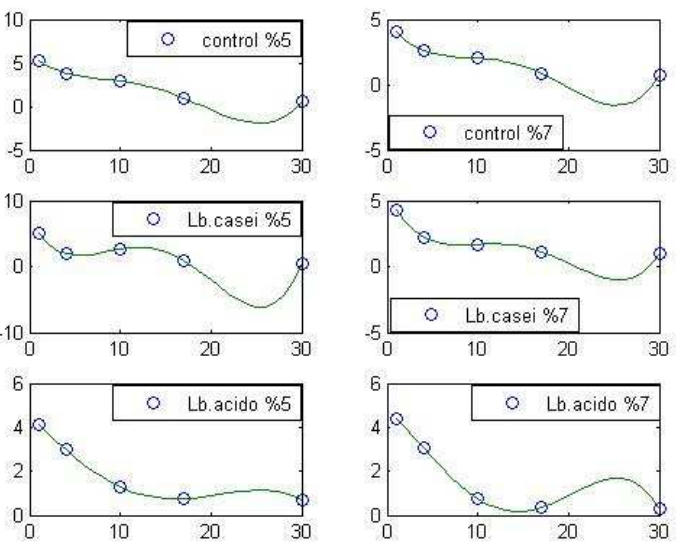

Figure 10. The graphics of the membership functions for yeast and mold numbers (the $\mathrm{x}$-axis represent the days and the $y$-axis represent the yeast and mold numbers).

The following membership function was defined

$$
\mu_{i}^{y m}(x)=\frac{y m_{i}(x)}{10^{n}},
$$

The following membership function was defined

$$
\mu_{i}^{l a b}(x)=\frac{l a b_{i}(x)}{10^{n}}
$$

for all $i \in\{1,2,3,4,5,6\}$, where $n$ is the number of digits of the integer part of $l a b_{i}(x)$.

Case 5: Using the results given in Figure 4, the following functions for yeast - mold numbers were chosen (see Figure 10):

$y m_{1}(x)=0.0001 x^{4}-0.0069 x^{3}+0.1173 x^{2}$

$-0.9326 x+6.0921$,

$y m_{2}(x)=0.0001 x^{4}-0.0073 x^{3}+0.1321 x^{2}$

$-1.0078 x+4.9329$,

$y m_{3}(x)=0.0004 x^{4}-0.0238 x^{3}+0.4215 x^{2}$

$-2.7341 x+7.4959$,

$y m_{4}(x)=0.0001 x^{4}-0.0086 x^{3}+0.1700 x^{2}$

$-1.3615 x+5.4800$,

$y m_{5}(x)=0.0010 x^{3}+0.0018 x^{2}-0.4209 x+4.5682$,

$y_{6}(x)=-0.0001 x^{4}+0.0038 x^{3}-0.0392 x^{2}$

$-0.3070 x+4.7125$,

where $x \in\{1,4,10,17,30\}$. for all $i \in\{1,2,3,4,5,6\}$, where $n$ is the number of digits of the integer part of $y m_{i}(x)$.

The fuzzy soft sets $\left(F_{x, i}, E_{i}\right), i=1$ to 6 were constructed by considering the membership values $\mu_{i}^{p h}(x), \mu_{i}^{l b}(x), \mu_{i}^{l a}(x), \mu_{i}^{l a b}(x)$ and $\mu_{i}^{y m}(x)$. It can be defined

$$
\begin{aligned}
& \left(F_{x, i}, E_{i}\right)=F_{i} \\
& =\left\{\frac{p h}{\mu_{i}^{p h}(x)}, \frac{l c}{\mu_{i}^{l c}(x)}, \frac{l a}{\mu_{i}^{l a}(x)}, \frac{l a b}{\mu_{i}^{l a b}(x)}, \frac{y m}{\mu_{i}^{y m}(x)}\right\},
\end{aligned}
$$

where $i \in\{1,2,3,4,5,6\}$ and $x \in$ $\{1,4,10,17,30\}$.

Now it can be investigated fuzzy soft sets for $x=30$ and $i=1$ to 6 .

$$
\begin{aligned}
& \left(F_{30,1}, E_{1}\right)=F_{1}(\text { control \%5) } \\
= & \left\{\frac{p h}{0.334}, \frac{l c}{0}, \frac{l a}{0}, \frac{l a b}{0.797}, \frac{y m}{0.52}\right\} . \\
& \left(F_{30,2}, E_{2}\right)=F_{2}(\text { control \%7) } \\
= & \left\{\frac{p h}{0.339}, \frac{l c}{0}, \frac{l a}{0}, \frac{l a b}{0.783}, \frac{y m}{0.67}\right\} . \\
\left(F_{30,3}, E_{3}\right)=F_{3}(\text { Lb.casei } \% 5) & =\left\{\frac{p h}{0.339}, \frac{l c}{0.871}, \frac{l a}{0}, \frac{l a b}{0.876}, \frac{y m}{0.34}\right\} .
\end{aligned}
$$




$$
\begin{aligned}
& \left(F_{30,4}, E_{4}\right)=F_{4}(\text { Lb.casei \% }) \\
& =\left\{\frac{p h}{0.332}, \frac{l c}{0.785}, \frac{l a}{0}, \frac{l a b}{0.777}, \frac{y m}{0.95}\right\} . \\
& \left(F_{30,5}, E_{5}\right)=F_{5}(\text { Lb.acido \%5) } \\
& =\left\{\frac{p h}{0.336}, \frac{l c}{0}, \frac{l a}{0.818}, \frac{l a b}{0.847}, \frac{y m}{0.66}\right\} . \\
& \left(F_{30,6}, E_{6}\right)=F_{6}(\text { Lb.acido \% } 7) \\
& =\left\{\frac{p h}{0.339}, \frac{l c}{0}, \frac{l a}{0.813}, \frac{l a b}{0.843}, \frac{y m}{0.28}\right\} .
\end{aligned}
$$

By a similar way, other fuzzy soft sets can be defined for $x \in\{1,4,10,17\}$ and $i=1$ to 6 .

A results' table can be constructed to see the most accurate and adequate predictions in the research. It can be written " 1 " for the largest value of the membership function for each parameter $E_{i}, i=1$ to 6 and " 0 " for other values. Then the row which has the top " 1 " score is chosen for the prediction. It can be seen from the Table 3 parameter $E_{3}$ is the optimum salt concentration for our research.

As it is seen from the Table 3, this model could accurately and adequately predict the growths of Lb. casei, Lb. acidophilus, total lactic acid bacteria and yeasts in pickles. And it can be shown that pickles with $5 \%$ (w/v) salt concentrations and $L b$. casei culture gave the highest scores in this study.

Table 3. The results for $x=30$ and $i=1$ to 6 .

\begin{tabular}{|c|c|c|c|c|c|c|}
\hline & $p h$ & $l c$ & $l a$ & $l a b$ & $y m$ & sensory scores \\
\hline$E_{1}$ & 0 & 0 & 0 & 0 & 0 & 0 \\
\hline$E_{2}$ & 1 & 0 & 0 & 0 & 0 & 0 \\
\hline$E_{3}$ & 1 & 1 & 0 & 1 & 0 & 1 \\
\hline$E_{4}$ & 0 & 0 & 0 & 0 & 0 & 0 \\
\hline$E_{5}$ & 0 & 0 & 1 & 0 & 0 & 0 \\
\hline$E_{6}$ & 1 & 0 & 0 & 0 & 1 & 0 \\
\hline
\end{tabular}

\section{Discussions}

Heterofermentative LAB are more sensitive to high salt concentrations than homofermentatives. Therefore high salt levels favor the growth of homofermentative LAB and resulting in an accelerated production of lactic acid. Maintaining the viability (minimum numbers of probiotic cultures present in the final product recommended to be $10^{6} \mathrm{cfu} / \mathrm{ml}$ or higher) and the activity of lactic acid bacteria in foods to the end of shelf life are two important criteria [27.
Salt concentration can affect the growth of the naturally present microorganisms and the sensory properties of the pickles [28. In the following studies they have shown potential benefits of using starter cultures in low-salt pickle fermentations. In Xiong et al. 29] study unfavorable conditions resulting from low $\mathrm{pH}$ contributed to the rapid decline of the lactococci as fermentation progressed. Similarly, Weng et al. 30] found that $\mathrm{NaCl}$ concentration affects the growth of $L$. citreum L-33 in pickle and the specific growth rate decreases with the increase of $\mathrm{NaCl}$ concentration. It also demonstrated that less salt addition can lead to a rapid growth for the important lactic acid bacteria in pickling production. Beganovic et al. 28] showed that the application of the probiotic strain $L b$. plantarum L4 together with Lc. mesenteroides LMG 7954, positively influenced the fermentations by improving the quality of the final product with added probiotic properties, considerably shortening the fermentation time and offering the possibility of low salt fermentations $(2.5 \mathrm{w} / \mathrm{v})$. The rapid increase in acidity minimizes the influence of spoilage bacteria. Reducing the influence of spoilage bacteria would most probably improve the microbiological and sensory quality of the fermented end product significantly (see [31] and 32] for more details).

Yoon et al. 33] researched red beet juice fermentation with $L b$. acidophilus, $L b$. casei, Lb. delbrueckii and $L b$. plantarum in their study. They found that $L b$. acidophilus in fermented beet juice could be remained at $10^{6}-10^{8} \mathrm{cfu} / \mathrm{ml}$ after 4 weeks of cold storage and the others lost their viability. In this study, all viable numbers after the storage were $>10^{6} \mathrm{cfu} / \mathrm{g}$ and it can be considered pickles have probiotic meaning health of view (Figures 1 and 21). Lb. acidophilus numbers reached max. $8.8 \log \mathrm{cfu} / \mathrm{g}$ on the $17^{\text {th }}$ day of storage in pickles with $5 \%(\mathrm{w} / \mathrm{v})$ and $7 \%(\mathrm{w} / \mathrm{v})$ salt concentration brine. On the $30^{\text {th }}$ day, bacteria numbers were very close to each other and declined to $8.13 \log \mathrm{cfu} / \mathrm{g}$.

LAB produce several antimicrobials, including organic acids (lactic, acetic, formic, phenyllactic, caproic acids) carbondioxide, hydrogen peroxide, diacetyl, ethanol, bacteriocins, reuterin and reutericyclin and they can prevent mould spoilage and growth of some pathogenic bacteria (see [8], [34 and 35] for more details). It can be concluded that these specific lactic acid bacteria in pickles were able to produce bacteriocins that inhibit yeasts at the last of storage.

Using bacterial cultures must not only aim at expressing functional properties upon microbial growth, but also at the impact on other quality 
changes in the pickles. Among these changes, the sensory or organoleptic property is the most important [13]. In Weon and Lee [36] study, perception and preference of low salt Korean pickle "Jangachi" were evaluated. Low sodium Jangachi was found safe, sanity, safekeeping and the most preferred by the consumers.

\section{Conclusions}

Researches' results provided a useful basis for further studies of the development of optimization sodium chloride concentration level in brine during fermentation of pickles. It was demonstrated that concentration of sodium chloride in brine solution have significant effects on the growths of $L b$. acidophilus, $L b$. casei, total lactic acid bacteria and yeast counts during fermentation. The population dynamics during cabbage-carrot pickle fermentation can be predicted by the use of the notion of fuzzy soft set at the same production conditions. Application of "fuzzy soft set" in optimization of pickle fermentation helps and allows better understanding of the interaction between the variables.

Acknowledgement 1. The authors would like to thank the anonymous referees for their comments that helped us improve this article.

\section{References}

[1] Tokatlı, M., Gülgör, G., Elmacı, S.B., İşleyen, N.A., Özçelik, F. (2015). In vitro properties of potential probiotic indigenous lactic acid bacteria originating from traditional pickles. BioMed. Res. Int., 1, 1-8.

[2] Tamang, J.P., Tamang, B., Schillinger, U., Guigas, C., Holzapfel, W.H. (2009). Functional properties of lactic acid bacteria isolated from ethnic fermented vegetables of the Himalayas. Int. J. Food Microbiol., 135, 28-33.

[3] Divya, J.B., Varsha, K.K., Madhavan, K., Ismail, N.B., Pandey, A. (2012). Probiotic fermented foods for health benefits. Eng. Life Sci., 12, 377-390.

[4] Kos, B., Suskovic, J., Beganovic, J., Gjuracic, K., Frece, J., Iannaccone, C., Canganella, F. (2008). Characterization of the three selected probiotic strains for the application in food industry. World J. Microbiol. Biotechnol., 24, 699-707.

[5] Surh, J., Kim, Y.K.L., Kwon, H. (2008). Korean fermented foods: Kimchi and Doenjang. In Handbook of Fermented Functional Foods. Edward, R.; Farnworth, T., Eds.; CRC Press, US 333-353.

[6] Nagpal, R., Kumar, A., Kumar, M., Behare, P.V., Jain, S., Yadav, H. (2012). Probiotics, their health benefits and applications for developing healthier foods: a review. FEMS Microbiol. Lett., 334, 1-15.

[7] Wacher, C., Diaz-Ruiz, G., Tamang, J.P. (2010). Fermented Vegetable Products. In Fermented Foods and Beverages of the World; Tamang J.P. ; Kaialasapathy, K., Eds.; CRC Press, US 149-190.
[8] Zhou, F., Zhao, H., Bai, F., Dziugan, P., Liu, Y., Zhang, B. (2014). Purification and characterisation of the bacteriocin produced by Lactobacillus plantarum, isolated from Chinese pickle. Czech J. Food Sci., 32, 430-436.

[9] Bengmark, S. (2010). Lactic acid Bacteria and Plant Fibers: Treatment in acute and chronic human disease. In Prebiotics and Probiotics ingredients, Health Benefits and Food Applications; Cho, S.S.; Finocchiaro, E.T., Eds.; CRC Press, US 163-192.

[10] Montet, D., Ray, R.C., Zakhia-Rozis, N. (2015). Lactic acid fermentation of vegetables and fruits. In $\mathrm{Mi}$ croorganisms and Fermentation of Traditional Foods; Ray R.C.; Montet D., Eds.; CRC Press, US 108-141.

[11] Furtado-Martins, E.M., Ramos, A.M., Vanzela, E.S.L., Stringheta, P.C., Pinto, C.L.O., Martins, J.M. (2013). Products of vegetable origin: A new alternative for the consumption of probiotic bacteria. Food Res. Int., 51, 764770.

[12] Yoon, K.Y., Woodams, E.E., Hang, Y.D. (2009). Production of probiotic cabbage juice by lactic acid bacteria. Biores. Technol., 97, 14271430.

[13] Zhao, D., Ding, X. (2008). Studies on the low-salt Chinese potherb mustard (Brassica juncea, Coss.) pickle. I-The effect of a homofermentative L(+) -lactic acid producer Bacillus coagulans on starter culture in the low-salt Chinese potherb mustard pickle fermentation. LWT-Food Sci. Technol., 41(3), 474-482.

[14] Penas, E., Frias, J., Sidro,B., Vidal-Valverde, C. (2010). Impact of fermentation conditions and refrigerated storage on microbial quality and biogenic amine content of sauerkraut. Food Chem.. 123, 143-150.

[15] Lin, S.H., Li, Y. H., Leung, K., Huang, C.Y., Wang, X.R. (2014). Salt processed food and gastric cancer in a Chinese population. As. Pac. J. Cancer Prev., 15(13), 5293-5298.

[16] Kalaichelvi, A., Malini, P. H. (2011). Application of fuzzy soft sets to investment decision making problem. Int. J. Math. Sci. Appl., 1(3), 1583-1586.

[17] Yüksel, S., Dizman, T., Yıldızdan, G., Sert, U. (2013). Application of soft sets to diagnose the prostate cancer risk. J. Inequal Appl., 1, 229-240.

[18] Özgür, N.Y., Tas, N. (2015). A note on "Application of Fuzzy Soft Sets to Investment Decision Making Problem". J. New Theory., 1(7), 1-10.

[19] Maji, P.K., Biswas, R., Roy, A.R. (2002). An Application of Soft Set in a Decision Making Problem. Comput. Math. Appl. 44(8-9), 1077-1083.

[20] Roy, A.R., Maji, P.K. (2007). A Fuzzy Soft Set Theoretic Approach to Decision Making Problems. J. Comput. Appl. Math., 203(2), 412-418.

[21] Ng, E.W.Y. (2009). Effect of starter cultures on Lactobacillus acidophilus and gene expression in yogurt. Thesis of California Polytechnic State University, San Luis Obispo, US 108 p.

[22] Oh, S., Rheem, S., Sim, J., Kim, S., Baek, Y.J. (1995). Optimizing Conditions for the Growth of Lactobacillus casei YIT 9018 in Tryptone-Yeast ExtractGlucose Medium by Using Response Surface Methodology. Appl. Environ. Microbiol., 61(11), 3809-3814.

[23] Zhao, D., Tang, J., Ding, X. (2007). Analysis of volatile components during potherb mustard (Brassica juncea, Coss.) pickle fermentation using SPMEGC-MS. LWT-Food Sci. Technol., 40, 439-447.

[24] Inatsu, Y., Bari, M.L., Kawasaki, S., Kawamoto, S. (2005). Effectiveness of some natural antimicrobial 
compounds in controlling pathogen or spoilage bacteria in lightly fermented Chinese cabbage. J. Food Sci., 70(9), 393-397.

[25] Jagannath, P., Raju, P.S., Bawa, A. S. (2012). A Twostep controlled lactic fermentation of cabbage for improved chemical and microbiological qualities. J. Food Qual., 35, 13-20.

[26] Maji, P.K., Biswas, R., Roy, A.R. (2001). Fuzzy Soft Sets. J. Fuzzy Math., 9, 589-602.

[27] Kearney, N., Stanton, C., Desmond, C., Coakley, M., Collins, J. K., Fitzgerald, G., Ross, R.P. (2008). Challenges associated with the development of probioticcontaining Functional foods. In Handbook of Fermented Functional Foods; Edward, R.; Farnworth, T., Eds.; CRC Press, US 25-71.

[28] Beganovic, J., Pavunc, A. L., Gjuracic, K., Spoljarec, M., Suskovic, J., Kos, B. (2011). Improved sauerkraut production with probiotic strain Lactobacillus plantarum L4 and Leuconostoc mesenteroides LMG 7954. J. Food Sci. 76(2), 124-129.

[29] Xiong, T., Guan, Q., Song, S., Hao, M., Xie, M. (2012). Dynamic changes of lactic acid bacteria flora during Chinese sauerkraut fermentation. Food Control. 26, 178-181.

[30] Weng, P.F., Wu, Z.F., Lei, L.L. (2013). Predictive models for growth of Leuconostoc citreum and its Dynamics in pickled vegetables with low salinity. J. Food Proces. Eng., 36, 284-291.

[31] Viander, B., Maki, M.M., Palva, A. (2003). Impact of low salt concentration, salt quality on natural largescale sauerkraut fermentation. Food Microbiol., 20, 391-395.
[32] Cvetkovic, B.R., Pezo, L. L., Tasic, T., Saric, L., Kevresan, Z., Mastilovic, J. (2015). The optimisation of traditional fermentation process of white cabbage (in relation to biogenic amines and polyamines content and microbiological profile). Food Chem. 168, 471-477.

[33] Yoon, K.Y., Woodams, E. E., Hang, Y. D. (2005). Fermentation of beet juice by beneficial lactic acid bacteria. LWT-Food Sci. Technol., 38, 73-75.

[34] Irkin, R., Songun, G.E. (2012). Applications of probiotic bacteria to the vegetable pickle products. Sci. Rev. Chem. Com., 2(4), 562-567.

[35] Heperkan, D. (2013). Microbiota of table olive fermentations and criteria of selection for their use as starters. Front. Microbiol., 4(143), 1-11.

[36] Weon, M.K., Lee, Y.J. (2013). Consumer's perception, preference and intake frequency of Jangachi (Korean Pickle) by age for developing low salt Jangachi. Korean J. Cul. Res., 19(5), 249-263.

Reyhan Irkin is currently an associate professor at Izmir Democracy University in Turkey. Her research interests include food microbiology.

Nihal Yalmaz Özgür is currently a professor at Balıkesir University in Turkey. Her research interests include complex functions with one variable, soft set theory and fixed point theory.

Nihal Taş is currently a research assistant at Balikesir University in Turkey. Her research interests include topological spaces, soft set theory and fixed point theory.

An International Journal of Optimization and Control: Theories \& Applications (http://ijocta.balikesir.edu.tr)

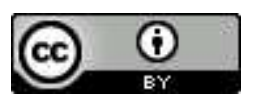

This work is licensed under a Creative Commons Attribution 4.0 International License. The authors retain ownership of the copyright for their article, but they allow anyone to download, reuse, reprint, modify, distribute, and/or copy articles in IJOCTA, so long as the original authors and source are credited. To see the complete license contents, please visit http://creativecommons.org/licenses/by/4.0/. 